\title{
UJI KERAPUHAN GRANUL PATI PADI DENGAN METODE GRANULASI BASAH
}

\author{
Bagus Alam ${ }^{1}$, Tya Muldiyana*2 \\ 1,2,Prodi Farmasi, Fakultas Ilmu Kesehatan, Universitas Muhadi Setiabudi Brebes, Jawa Tengah \\ Indonesia \\ Email corresponden*: ${ }^{2}$ tya muldiyana@yahoo.com
}

\begin{abstract}
Abstrak
Padi merupakan bahan makanan pokok bagi masyarakat dunia dan sering digunakan dalam pengolahan makanan, selain itu padi juga dapat digunakan dalam bidang farmasi sebagai bahan pengisi, pengikat dan penghancur dengan cara di ambil patinya. Oleh karna itu dirumuskan permasalahan sebagai berikut, bagaimanakah tingkat kerapuhan granul pati padi dengan metode granulasi basah. Tujuan dari penelitian ini untuk mengetahui tingkat kerapuhan granul pati padi dengan metode granulasi basah. Tahap pertama pembuatan granul pati padi yaitu penggilingan padi menjadi beras. Tahap kedua dilanjutkan dengan pembuatan beras menjadi pati. Tahap ketiga dilanjutkan dengan pembuatan granul pati padi. Setelah granul pati padi didapat, tahap berikutnya dilakukan uji kerapuhan terhadap granul pati padi yaitu dengan cara granul yang telah dibuat ditimbang sebanyak 100 gram. Granul yang telah ditimbang dimasukkan ke dalam ayakan, dan diputar sebanyak sepuluh kali. Kemudian menghitung banyaknya granul yang jatuh dan dihitung persentasenya. Semakin kecil presentase kerapuhan granul maka granul yang dihasilkan akan semakin baik. Hasil uji kerapuhan granul pati padi dengan metode granulasi basah yaitu 0,54 \%. Hasil tersebut menunjukan bahwa kerapuhan dari granul pati padi baik karena presentase kerapuhan dari $1 \%$. Hasil penelitian ini diharapkan dapat memberikan alternatif sumber bahan tambahan sediaan farmasi dari bahan alam lokal yang ketersediaannya banyak.
\end{abstract}

Kata kunci: Padi, pati, metode granulasi basah, granul

\begin{abstract}
Rice is a staple good for the world community and is often used in food processing, but rice can also be used in the pharmaceutical field as filler, binder and crusher by the way it is takken. Because it is formulated the following problem, how is the fragillity level of rice starch granules with wet granulation method. The purpose to Determine the level of fragility of rice starch granules with wet granulation method. The first stage of making rice starch granules is rice grinding into ricee. The second stage is followed by making rice into starch. The third stage is followed by the making of starch granules. After grain starch granules are obtained, the next step is to test the fragility of rice starch granules is by granules the have been made weighed as much as 100 grams. The weighed granules where inserted into a sieve, and played ten times. Then calculate the number of granules that fall and calculated the percentage. The smaller the percentage of granule fragility, the resulting granules will be better. The result of gray starch granules fragrance test with wet granulation method is $0,54 \%$. The results show that the fragility of rice starch granules is good because of the percentage of fragility of 1\%. The results of this study are expected to provide and alternative source of additional pharmaceutical ingradients from lokal natural materials that are widely available.
\end{abstract}

Keywords: starch, granulation method, granules.

Submitted: Juli 2019, Accepted: Juli 2019, Published: Agustus 2019

ISSN: xxxx-xxxxx (online), Website: http://jurnal.umus.ac.id/index.php/jophus 


\section{PENDAHULUAN}

Padi merupakan makanan utama di beberapa negara berkembang dengan menyumbang $4.000 \mathrm{~kJ}$ energi per kapita per hari.Komposisi dan sifat biji padi dan bagian-bagiannya tergantung pada varietas, lingkungan dan ragam pengolahannya. Kandungan yang terkandung dalam padi yaitu karbohidrat sebesar 360 kalori, protein sebesar 6,8 gr, dan kandungan mineral seperti kalsium dan zat besi masing-masing $6 \mathrm{mg}$ dan $0,8 \mathrm{mg}$, sebagian terbesar karbohidrat dalam beras ialah pati dan hanya sebagian kecil pentosan, selulosa, hemiselulosa, dan gula. Pati yang terkandung dalam beras berkisarantara $85 \%$ - 90\% dari berat kering.

Pati merupakan kandungan utama beras $( \pm 75 \%)$ yang terdapat dalam bagian endosperm berbentuk granula majemuk berukuran 3-10 $\mu \mathrm{m}$. Berbagai macam pati tidak sama sifatnya, tergantung dari panjang rantai atom karbonnya, serta lurus atau bercabang.[2] Dalam bentuk aslinya secara alami pati merupakan butiran-butiran kecil yang sering disebut granula. Bentuk dan ukuran granula merupakan karakteristik setiap jenis pati, karena itu digunakan untuk identifikasi. Penggunaan pati sebagai eksipien dalam bidang farmasi masih sangat dibutuhkan. Dalam formulasi tablet pati digunakan sebagai bahan pengisi, pengikat dan bahan penghancur.[3]

Granul tidak hanya merupakan produk antara pada proses pembuatan tablet, akan tetapi granul yang mengandung zat aktif merupakan sediaan obat tersendiri. Dalam skala besar, banyak campuran serbuk yang diubah menjadi granulat, agar lebih baik penggunaannya dan takarannya lebih pasti. Bahan yang dibutuhkan dalam pembuatan granul, berfungsi sebagai bahan pengisi, bahan pengikat, bahan penghancur dan bahan pelicin.[4]

Dalam pembuatan granul terdapat beberapa uji untuk menguji apakah granul tersebut layak digunakan atau tidak. Salah satu pengujian untuk granul adalah uji kerapuhan granul. Uji ini dilakukan dengan tujuan untuk mengukur ketahanan permukaan granul terhadap gesekan atau getaran yang terjadi pada granul.

Penelitian sebelumnya dilakukan oleh Siska Apriyanti, menggunakan pati bonggol pisang hasil uji kerapuhan granul pati bonggol pisang dengan metode granulasi basah yaitu $0,24 \%$, hasil tersebut menunjukan bahwa kerapuhan dari granul pati bonggol pisang baik karena persentase kerapuhan kurang dari 1\%.[5] Dan dilakukan dengan tiga tahap yaitu tahap pertama pembuatan pati, tahap kedua dilanjutkan dengan pembuatan granul pati, setelah granul pati didapat, tahap berikutnya dilakukan uji kerapuhan terhadap granul pati.[6] Dan juga dilakukan oleh Eka Ari Ramdani dkk, uji kerapuhan dimaksudkan agar diperoleh granul yang memiliki mutu dan kualitas yang baik. Oleh karena itu penulis tertarik untuk melakukan penelitian dengan judul Uji Kerapuhan Granul Pati Padi Dengan Metode Granulasi Basah

Adapun tujuan dari penelitian ini adalah untuk mengetahui kerapuhan granul pati padi dengan metode granulasi basah. Agar penelitian yang dilakukan sesuai dengan tujuan awal, maka penulis batasi yaitu uji yang dilakukan dalam penelitian granul pati beras menentukan kerapuhan

\section{METODE PENELITIAN}

\section{Metode Penelitian}

Metode yang digunakan dalam penelitian ini adalah metode penelitian eksperimen. Metode eksperimen (percobaan) adalah suatu tuntutan dari perkembangan ilmu pengetahuan dan teknologi agar menghasilkan suatu produk yang dapat dinikmati masyarakat secara aman dan dalam pembelajaran melibatkan siswa dengan mengalami dan membuktikan sendiri proses dan hasil percobaan itu. 
Alat Dan Bahan

Tabel1. Daftar alat yang digunakan dalam penelitian

\begin{tabular}{|c|c|}
\hline No & Nama Alat \\
\hline 1 & Beaker glass $500 \mathrm{ml}$ \\
\hline 2 & Batang pengaduk \\
\hline 3 & Gelas ukur $100 \mathrm{ml}$ \\
\hline 4 & Ayakan no. 6-12 mesh \\
\hline 5 & Kaos tangan karet \\
\hline 6 & Timbangan teknis (neraca) \\
\hline 7 & Oven \\
\hline 8 & Hot plate \\
\hline 9 & Ayakan kawat no. 80 mesh \\
\hline 10 & Nampan \\
\hline 11 & Cawan Porselen \\
\hline
\end{tabular}

Tabel 2. Daftar bahan yang digunakan dalam penelitian

\begin{tabular}{|c|l|}
\hline No & \multicolumn{1}{|c|}{ Nama Bahan } \\
\hline 1 & $\begin{array}{l}\text { Pati padi diperoleh dari pasar Kersana Kec. Kersana Kab. Brebes yang } \\
\text { sudah di haluskan menjadi pati di Lab Farmasi Universitas Muhadi } \\
\text { Setiabudi, berupa serbuk halus kadang kadang berupa gumpalan kecil, } \\
\text { warna putih tidak berbau,dan tidak berasa }\end{array}$ \\
\hline 2 & $\begin{array}{l}\text { Laktosa (C12H22O11) diperoleh dari Lab Farmasi Universitas Muhadi } \\
\text { Setiabudi berupa serbuk halus, berwarna putih }\end{array}$ \\
\hline 3 & Aquades (H2O) diperoleh dari Lab Farmasi Universitas Muhadi Setiabudi \\
\hline 4 & Gelatin diperoleh dari Lab Farmasi Universitas Muhadi Setiabudi \\
\hline
\end{tabular}

\section{Cara Kerja}

\section{Pembuatan Pati Padi}

Padi yang akan dibuat pati digiling terlebih dahulu, lalu akan menghasilkan beras setelah menjadi beras, beras tersebut harus dibersihkan terlebuh dahulu, menggunakan air, lalu setelah bersih digiling kembali beras tersebut agar menghasilkan partikel yang lebih kecil dari beras yang disebut pati, lalu campurkan pati dengan aquadest dengan maksud menghilangkan kotoran dari sisa penggilingan, setelah benar-benar bersih keringkan hinggga benar-benar kering, setelah benar-benar kering barulah didapat pati padi ( amillum oryzae sativa). Adapun skema tentang pembuatan terdapat pada Gambar 1.

\section{Pembuatan Granul Pati Padi}

Timbang semua bahan lalu membuat solution dengan cara gelatin dilarutkan dalam aquadest secukupnya, dan dipanaskan diatas hot plate hingga warna jernih. Kemudian mencampurkan pati dan laktosa hingga homogen, campuran tersebut diayak menggunakan ayakan kemudian untuk membuat massa granul, campuran tersebut ditambahkan solution gelatin yang telah dipanaskan, dan catat volume solution gelatin yang digunakan kemudian massa granul yang telah terbentuk diayak untuk mendapatkan butiran-butiran granul yang diinginkan menggunakan ayakan nomor 6 mesh kemudian granul yang telah terbentuk diletakkan diatas nampan yang telah dilapisi kertas perkamen dan dimasukkan kedalam oven sampai granul kering 
dengan suhu $60^{\circ} \mathrm{C}$ kemudian setelah kering keluarkan granul dari oven, dan didapat granul pati padi. Adapun skema tentang pembuatannya terdapat pada Gambar 2.

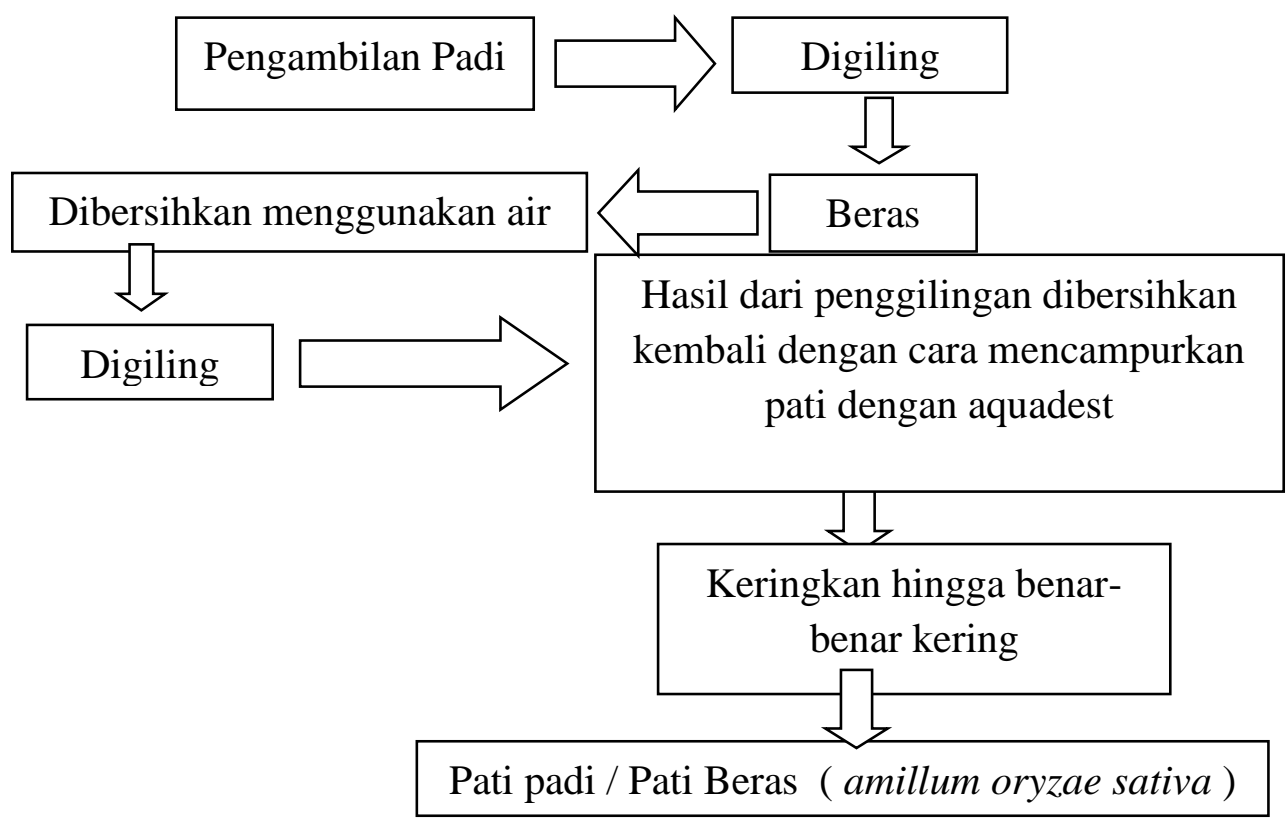

Gambar 1. Skema Pembuatan Pati Padi

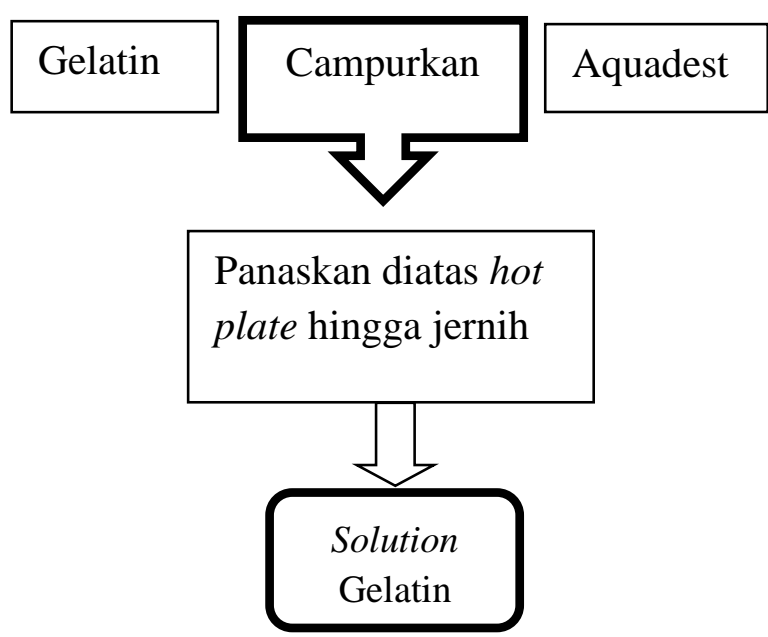

Gambar 2. Pembuatan Solution Gelatin 


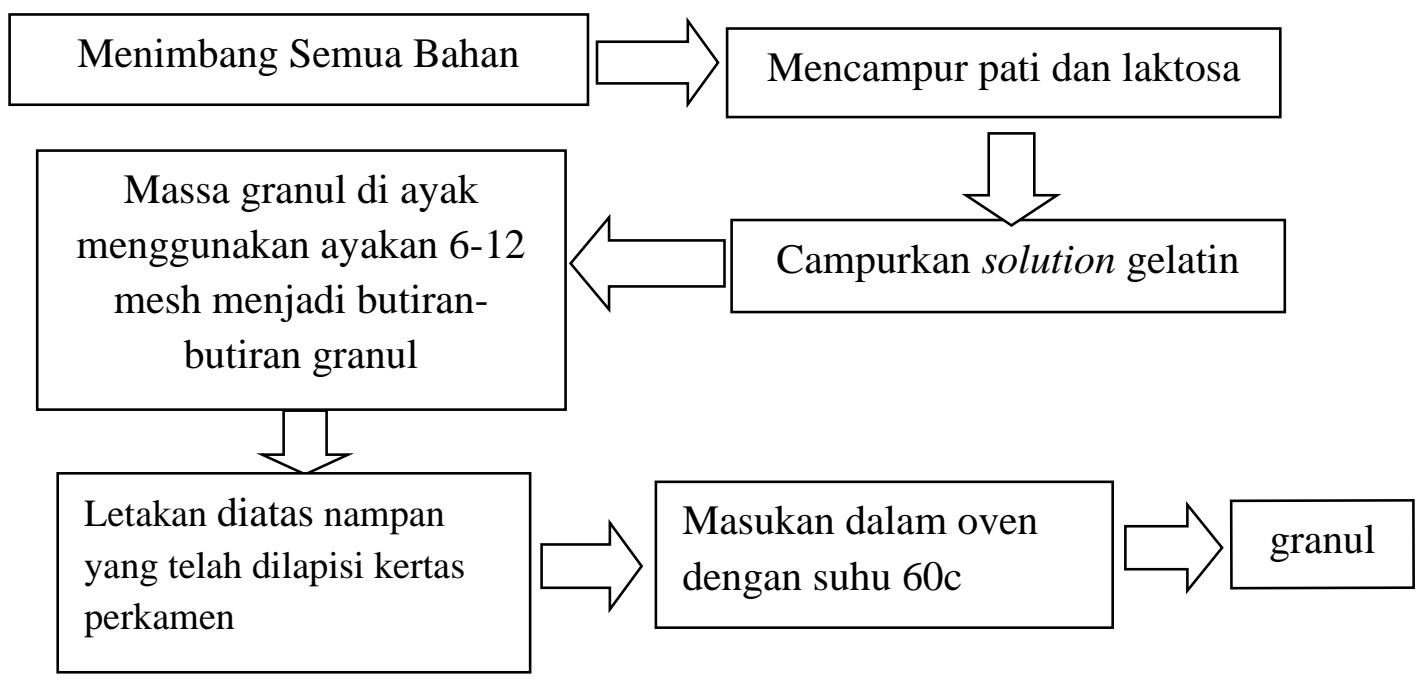

Gambar 3.Skema Pembuatan Granul Pati Padi

\section{Uji kerapuhan Granul Pati Padi}

Granul yang telah dibuat kemudian di timbang sebanyak seratus gram untuk dilakukan uji kerapuhan pada granul tersebut, kemudian granul yang sudah di timbang dimasukan ke dalam ayakan bertumpuk dan di putar sebanyak sepuluh kali kemudian timbang banyaknya granul yang jatuh kemudian hitung persentase kerapuhan granul tersebut. Semakin kecil persentase kerapuhan granul maka granul yang dihasilkan semakin baik. Setelah di peroleh granul yang baik hitunglah presentase granul dengan menggunakan rumus pengukuran kerapuhan granul.

Rumus pengukuran kerapuhan granul:

$$
\mathrm{F}=\frac{\mathrm{V}_{\mathrm{o}-\mathrm{Vt}}}{\mathrm{Vo}_{\mathrm{o}}} 100 \%
$$

\begin{tabular}{|c|c|}
\hline Ket: & \\
\hline $\mathrm{F}$ & $=$ Indeks Kerapuhan. \\
\hline Vo & $=$ Bobot Awal \\
\hline $\mathrm{Vt}$ & $=$ Bobot Akhir \\
\hline
\end{tabular}

\section{Hipotesis}

Adapun yang menjadi hipotesis dalam penelitian ini adalah sebagai berikut :

1. Tingkat kerapuhan granul pati padi tipe IR64 jenis Ciherang cukup baik.

2. Hasil pembuatan granul kurang maksimal. 


\section{HASIL DAN PEMBAHASAN}

\section{Pembuatan Pati Padi Tipe IR64 Jenis Ciherang}

Pada pembuatan pati padi digunakan padi tipe IR64 jenis Ciherang, dikarenakan padi IR64 ini yang umum digunakan di daerah Brebes, padi IR64 ini dari penggilingan 2,5 $\mathrm{kg}$ padi menghasilkan $2 \mathrm{~kg}$ pati. Dalam proses penggilingan padi akan mengalami penurunan bobot dari $2,5 \mathrm{~kg}$ menjadi $2 \mathrm{~kg}$, hal ini dikarenakan kulit padi yang terkelupas dalam proses penggilingan padi menjadi beras dan dalam proses penggilingan beras menjadi pati, terdapat penurunan bobot dikarenakan serbuk yang tertinggal dalam dinding mesin penggilingan.

Proses pembuatan pati padi IR64 jenis Ciherang yang akan dibuat pati ditimbang terlebih dahulu, lalu digiling, dan akan menghasilkan beras, beras tersebut harus dibersihkan terlebih dahulu menggunakan air, setelah bersih digiling kembali beras tersebut agar menghasilkan partikel yang lebih kecil dari beras yang disebut pati, selanjutnya campurkan pati dengan aquades dengan maksud menghilangkan kotoran dari sisa penggilingan, apabila sudah benar-benar bersih keringkan hingga benar-benar kering, setelah benar-benar kering barulah didapat pati padi ( Amillum oryzae sativa ).

\section{Pembuatan Granul Pati Padi Tipe IR64 Jenis Ciherang}

Proses pembuatan granul pati padi menggunakan metode granulasi basah dengan menggunakan bahan-bahan pembuatan yaitu laktosa, aquades, pati padi tipe IR64 jenis Ciherang ( Oryzae sativa) dan gelatin. Komposisi bahan pembuatan granul terdapat pada Tabel 3

Tabel 3. Pembuatan Granul Pati Padi

\begin{tabular}{|l|l|l|}
\hline No. & Bahan & Jumlah \\
\hline 1. & Pati Padi tipe IR64 jenis Ciherang (Oryza sativa) & 100 gram \\
\hline 2. & Laktosa & 70 gram \\
\hline 3. & Gelatin & 20 gram \\
\hline 4. & Aquades & $100 \mathrm{ml}$ \\
\hline
\end{tabular}

Laktosa adalah serbuk atau masa hablur keras putih atau putih krem, tidak berbau dan rasa sedikit manis, stabil diudara tetapi tidak mudah menyerap bau. Mudah dan pelan - pelan menyerap air, manfaat laktosa sebagai pengadsorpsi dan lebih mudah larut dalam air mendidih, sangat sukar larut dalam etanol, tidak larut dalam kloroform dan eter.

Gelatin merupakan lembaran, kepingan serbuk/butiran, tidak berwarna/kekuningan pucat, berbau lemah. Jika di rendam dalam air akan mengembang dan menjadi lunak, berangsur - angsur menyerap air $5-10$ bobotnya. Larut dalam air panas dan jika didinginkan terbentuk gudir, praktis tidak larut dalam etanol (95\%), dan air, jika dipanaskan lebih mudah larut, larut dalam basa asetat. manfaat sebagai pengikat dalam pembuataan granul.

Proses pembuatan granul dilakukan dengan cara mencampur semua bahan yaitu pati padi tipe IR64 jenis Ciherang 100 gram, laktosa 70 gram dan larutan gelatin yang telah dipanaskan hingga membentuk adonan yang homogen. Pada larutan gelatin dibuat dengan memanaskan 20 gram gelatin dan air $100 \mathrm{ml}$, didapat larutan gelatin sebanyak $100 \mathrm{ml}$, namun pada pembuatan adonan granul, larutan yang digunakan hanya $50 \mathrm{ml}$, dikarenakan apabila penggunaan solution gelatin terlalu banyak maka granul yang dihasilkan akan sangat keras.

Adonan yang telah kalis kemudian dibentuk menjadi granul dengan cara diayak menggunakan ayakan ukuran 12 mesh, adonan granul kemudian dikeringkan sampai kering menggunakan oven dengan suhu $60^{\circ} \mathrm{c}$ selama 5 menit. Untuk mendapatkan hasil granul yang rata dan bentuk yang seragam maka granul yang telah dikeringkan di ayak kembali menggunakan ayakan ukuran 16 mesh. Granul yang dihasilkan adalah 55 gram. Namun pada proses pengujian, 
granul yang diuji hanya 50 gram hal ini karna untuk mengantisipasi adanya granul yang jatuh atau hancur sebelum dilakukan sebelum dilakukan proses uji.

\section{Uji Kerapuhan Pati Padi Tipe IR64 Jenis Ciherang}

Jumlah granul yang di uji pada uji kerapuhan granul adalah 50 gram, pada penelitian ini komposisi bahan pembuatan granul tak sama seperti penelitian yang pernah dilakukan sebelumnya oleh Siska Apriyanti ( 2016 ), yang menggunakan komposisi pati dan laktosa dengan perbandingan $1: 2$, yaitu pati jauh lebih sedikit di banding laktosa. Sedangkan penelitian yang saya lakukan menggunakan perbandingan pati dengan lakttosa yaitu $2: 1$ dikarenakan pati yang ada sangat melimpah dibanding dengan laktosa pada saat pengujian.

Granul sebanyak 50 gram diuji dengan cara diayak menggunakan ayakan bertingkat dengan ukuran 20 mesh, 40 mesh, 60 mesh. Cara penggujian granul dilakukan dengan memutar ayakan atau menggerakkan ayakan ke atas bawah sebanyak 10 kali.

Hasil uji kerapuhan pati paditipe IR64 jenis Ciherang terdapat pada Tabel 4

Tabel 4. Hasil Uji Kerapuhan Pati Padi

\begin{tabular}{|l|l|l|}
\hline No. & Ukuran ayakan & Jumlah granul yang jatuh \\
\hline 1. & 20 mesh & 0,27 gram \\
\hline 2. & 40 mesh & - \\
\hline 3. & 60 mesh & - \\
\hline Jumlah & 0,27 gram \\
\hline
\end{tabular}

Perhitungan hasil uji kerapuhan pati tipe IR64 jenis Ciherang :

Hasil granul $=50$ gram $-0,27$ gram $=49.73$ gram

$F=\underline{\mathrm{Vo}-\mathrm{Vt}} \times 100 \%$

Vo

$=\underline{50 \text { gram }-49,73 \text { gram } \times 100 \%}$

50 gram

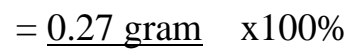

50 gram

$=0.54 \%$

Berdasarkan penelitian, presentase kerapuhan granul sebesar 0,54\%. Granul tersebut dianggap memiliki kerapuhan yang baik atau layak untuk diolah menjadi tablet. Hal ini ditunjukan dengan sedikitnya jumlah granul yang jatuh atau rapuh setelah digetarkan pada ayakan saat proses pengujian. Granul memiliki kerapuhan yang baik bisa disebabkan karena penggunaan gelatin sebagai zat pengikat. Granul yang baik memiliki sifat alir, sudut curah, derajat putih, bentuk dan ukuran granula, serta kapasitas pengikatair yang baik. Semakin besar harga presentase kerapuhan, maka semakin besar massa granul yang hilang. Dan kerapuhan granul dianggap baik bila kerapuhan tidak lebih dari $1 \%$

\section{KESIMPULAN}

Dari hasil penelitian uji kerapuhan granul pati padi tipe IR64 jenis Ciherang dengan metode granulasi basah dapat disimpulkan bahwa presentase kerapuhan granul patipadi tipe IR64 jenis 
Ciherang yaitu : $0,54 \%$. Dan granul dianggap baik karna presentase kerapuhan granul yang baik yaitu kurang dari $1 \%$.

\section{SARAN}

Dari hasil penelitian ini disarankan untuk dapat digunakan sebagai pertimbangan dalam pengembangan formulasi granul menggunakan pati padi tipe IR64 jenis Ciherang sebagai zat pengisi.

\section{DAFTAR PUSTAKA}

[1] Jane, J., 2006., Starch Properties, Modifications, and Application, Journal of Macromolecular Science. Part A Volume 32, Issue 4,751-757. Available https://www.tandfonline.com/doi/abs/10.1080/10601329508010286

[2] Firdaus, A. F., 2012, Sediaan tablet. Available : https://ahmadfiki.wordpress.com 12012/04/27/sediaan-tablet/. Diakses pada tanggal 30 maret 2017

[3] Suhery. W.N. dkk., 2015 Pembuatan dan Evaluasi Pati Talas (Colocasia esculenta Schoot). Termodifiasi dengan Bakteri Asam Laktat (Lactobacillus sp), Jurnal Sains Farmasi \& Klinis (e-ISSN: 2442-5435) | Vol. 01 No. 02. Available : http://jsfk.ffarmasi.unand.ac.id/index.php/jsfk/article/view/36

[4] Ainurofiq. A., Azizah. N., 2016, Perbandingan Penggunaan Bahan PenghancurSecaraIntragranular, Ekstragranular, Dan Kombinasinya, Journal of Pharmaceutical Science and Clinical Research 2016, 01, 1-9. Available : https://jurnal.uns.ac.id/jpscr/article/download/682/622

[5] Apriyanti, S., 2016, Uji Kerapuhan Granul Pati Bonggol Pisang Dengan Metode Granulasi Basah, Tugas Akhir, Program D3 Farmasi Fakultas Ilmu kesehatan Universitas Muhadi Setiabudi.

[6] Pratiwi. S.H., 2016, Pertumbuhan Dan Hasil Padi (Oryzasativa L.) Sawah Pada Berbagai MetodeTanam Dengan PemberianPupuk Organik, Gontor AGROTECH Science Journal Vol. 2 No. 2. Available : https://ejournal.unida.gontor.ac.id/index.php/agrotech/article/download/410/539

[7] Girisonta. 1990. Budidaya Tanaman Padi. Kanisius. Yogyakarta

[8] Nugrahani. I., dkk., 2005, Karakterisik Granul Dan Tablet Propranolol Hidroklorida Dengan Metode Granulasi Peleburan, Majalah Ilmu Kefarmasian Vol II No 2 ISSN : 1693-9883. Available

http://psr.ui.ac.id/index.php/journal/article/download/3387/465

[9] Setyanto. A. E., 2005, Memperkenalkan Kembali Metode Eksperimen dalam Kajian Komunikasi, Jurnal ilmu komunikasi, volume 3, nomor 1. Available : 
https://media.neliti.com/media/publications/100453-ID-memperkenalkankembali-metode-eksperimen.pdf

[10] Prabowo, S., 2006, Pengolahan Dan Pengaruhnya Terhadap Sifat Fisik Dan Kimia Serta Kualitas Beras, Jurnal Teknologi Pertanian Volume 1 No 2, available : https://jtpunmul.files.wordpress.com/2013/02/vol-12-1-sulistyo-prabowo.pdf

[11] Septia. S., 2015, Teknologi Sediaan Padat Pembuatan Tablet Paracetamol Dengan Cara Grranulasi Basah, http//: Septia Siska.blogspot.co.id. diakses 08/04/2017 